\title{
Dependency School and Its Relevance in Understanding the Nigerian State
}

\author{
Temitope Owolabi \\ Department of Sociology, University of Lagos
}

\begin{abstract}
Over the years, African political and development scholars, writers and commentators like Walter Rodney, Andre Gunder Frank, Frantz Fanon, Samir Amin, Peter Ekeh, Claude Ake among others have blamed the Europeans for the underdevelopment of Africa. This has necessitated the evocation of Dependency theory in explaining Africa's cum Nigeria's underdevelopment situation. Hence the study attempts to discuss this theme with special reference to its relevance and an understanding of the Nigerian state. Furthermore, the theory was a reaction to the modernization theory which explains a unilinear process for development in Africa. Secondary data was used specifically desk research and findings reveal that Africa cannot cast aspersions to the Europeans for its continued underdevelopment, but this can be tied majorly to its leadership inaction and bad governance. This we can see with high level of corruption, mal-administration, rent seeking and nepotism. This study further recommends that Nigeria should look inwards and take a cue from countries like China and India to develop it human and material deposits. Nigeria should jettison the mentality of colonialism and rewrite its own history itself, appropriate resources effectively towards the amelioration of the human condition, and lastly to build institutions that are transparent and accountable that will breed development and sustainable growth.
\end{abstract}

Keywords: Development, Underdevelopment, Dependency, Bad Leadership and Governance.

DOI: $10.7176 / \mathrm{JAAS} / 58-01$

Publication date:September $30^{\text {th }} 2019$

\section{INTRODUCTION.}

With respect to development discourse, sociologists believe that the primary and product of development is the upliftment of the human condition. In other words, amelioration of the human condition is the sub-stratum of development and over the years, African political and development scholars, writers and commentators have blamed the Europeans for the underdevelopment of African. This has necessitated the evocation of Dependency theory in explaining Africa's cum Nigeria's underdevelopment situation. The traditional neoclassical approach said virtually nothing on this question except to assert that the poorer countries were late in coming to solid economic practices and that as soon as they learned the techniques of modern economics, then the poverty would begin to subside. However, Marxists theorists viewed the persistent poverty as a consequence of capitalist exploitation. And a new body of thought, called the world systems approach, argued that the poverty was a direct consequence of the evolution of the international political economy into a fairly rigid division of labor which favored the rich and penalized the poor.

\section{OBJECTIVES OF THE STUDY}

The purpose of this study can be encapsulated as follows:

1. To discuss the concept of modernization as one of the sociological theories of development

2. To explore the dependency theory as a reaction to the modernization theory of development, including its forms and guiding principles.

3. To appraise the works and contributions of contemporary theorists of the dependency school in order to understand their ideologies and the direction of their theoretical positions.

4. To explore the understanding of the dependency theory and Nigeria's underdevelopment case.

\section{THE DEPENDENCY THEORY: AN OVERVIEW.}

Dependency theory is the notion that resources flow from a "periphery" of poor and underdeveloped states to a "core" of wealthy states, enriching the latter at the expense of the former. It is a central contention of dependency theory that poor states are impoverished and rich ones enriched by the way poor states are integrated into the "world system". A notable authority was W.W. Rostow thesis that suggested that a minimum specific proportion of national income to be directed to investment, which would make possible graduation into the take-off stage in development. He saw this automatic evolution taking place, the underdeveloped countries were at different points or stages on the road to development and mass consumption, but that the road was unique, in that all countries were destined to arrive at their target sooner or later, once they satisfied the conditions for the take-off (James, 1997).

In essence, the theory arose as a reaction to modernization theory, an earlier theory of development which held that all societies progress through similar stages of development, that today's underdeveloped areas are thus 
in a similar situation to that of today's developed areas at some time in the past, and that, therefore, the task of helping the underdeveloped areas out of poverty is to accelerate them along this supposed common path of development, by various means such as technology transfers and closer integration into the world market (Eme and Emeh, 2012).

Adegbagbo, Obinyan and Olurode (1990) also were of the opinion that the modernization perspective maintains that developing societies are going to catch up with the developed societies of the world, the more they become integrated into the latter's economies. The relationships between the indigenous social formations of African countries and the penetrating capitalist formations are interpreted as being functional and stable. It is assumed that with the diffusion of modernization influences from the West African societies would display similar features already exhibited by the developed economies during their transition to modernity. The development of these societies is therefore interpreted in terms of the transition from one Parsonian pattern variable to the other. Little wonder did Karl Marx argued that "countries of the world that are developed only show the less developed countries the images of their own future" (Olurode, 2017)

Dependency theory rejected this view arguing that underdeveloped countries are not merely primitive versions of developed countries, but has unique features and structures of their own; and, importantly, are in the situation of being the weaker members in a world market economy. Dependency theory no longer has many proponents as an overall theory, but some writers have argued for its continuing relevance as a conceptual orientation to the global division of wealth.

We should operationalise the major theme "Dependency", and it can be defined as "an explanation of the economic development of a state in terms of the external influences--political, economic, and cultural--on national development policies" (Ferraro, 1996). Here, the term dependency refers an important dimension of political economy of Third World countries: Both economy and politics in these countries are heavily affected by their dependence relationships with rich Western countries. The notion of dependency focuses on asymmetrical relationships and ties among nations, small groups and classes within the Third World and between the ones in Third World and the ones in Western World. In other words, although dependency is mostly seen between nations, it includes broader ties among classes and groups within and among nations who have common interests.

Furthermore, the dependency school of thought stresses that societies in the peripheral social formations and their local comprador bourgeoisie would never catch up with the developed economies of the world inasmuch as they remained incorporated into the world capitalist economy (Adegbagbo, Obinyan and Olurode, 1990). This school holds that participation in the world economy generates undevelopment rather than promotes development for the third world. The solution therefore is not further entrenchment into the global capitalist economy but a withdrawal from it.

Basically, dependency theory can be discussed from two (2) perspectives, the point of views of external and internal factors (Emeh, 2013). From the external factor for instance today through the aid of globalisation, the capitalist world order sets the agenda for investments almost all over the world. Investments in Middle Eastern countries have been insufficient through the years, because of the unstable situation there, and smaller chance of profit thereafter. Even the rich Arab states haven't invested much in the region. As long as the investments in the region are on that low level, and the trade deficit threatens the countries' financial resources, the dependence on aid and on borrowed funds seems crucial for the Middle East nations. The developed countries have always opposed change in the structure of power allocation in the international economic order, basically because of their benefits of today's status quo.

Internal factor, although less crucial than the external factor, should not be underestimated. In the postcolonial period, the former colonial powers made the use of people that could take care of their interests in the country. These people were of course people in leading positions that could affect decisions in the country. Big land-owners, business-men and the elite in the developing countries doing business with the elite in the developed countries are exploiting their native countrymen for their own benefit, in co-operation with the Western countries (Richards and Waterbury, 1996). This happened in the Middle East and Africa like in any other part of the world during the colonial age (Rapley, 1996). Therefore, dependence of the developing countries on developed countries should be attributed to external factors explained thus far as well as to insufficient internal dynamics.

\section{MAJOR PROPOSITIONS OF DEPENDENCY THEORY}

Firstly, it states that the Third World countries do not exist in isolation. They can only be understood in the context of the world economic and political system. Political events in Third World countries are directly related to events in First World countries. However, relations between First and Third World countries are asymmetrical. The flow of power and control is from the First World (center or core) to the Third World (periphery). Also, within the world political and economic system there is a tremendous amount of interaction among core countries and peoples, and between the core and the periphery. There is very little interaction just among 
periphery countries. The consequences of this are great, resulting in an isolated and weak periphery country having an unequal relationship with the united and strong core.

Politics and economics are related. They cannot be understood apart from each other. Economic ties and relationships between core and periphery countries are particularly important. These are advantageous for the core, and disadvantageous for the periphery. Core-periphery trading patterns result in continuous growth of political and economic power for the core at the expense of the periphery. Economic trade causes a widening of the gap between developed and developing countries, rather than a narrowing of that gap. Historically, lower priced raw materials have been exchanged for higher priced finished goods.

Lastly, underdevelopment is not a natural state, but rather a condition that is caused. The fact is that developed nations are actively under developing Third World countries as a result of the systems of interactions between them.

\section{FORMS OF DEPENDENCY}

\section{- Historical Dependency}

Historically, wealthy nations have taken a great quantity of materials from poor countries, such as minerals and metals necessary to make automobiles, weapons, and jewellery. Large amounts of agricultural products that can only be grown in the hot climates of the poor countries, such as coffee, tea, sugar, and cocoa, have been exported to and manufactured in the wealthy countries. Wealthy countries would not be as rich as they are today if they did not have these materials. Wealthy countries increased their own profits by organizing cheap labor through slavery.

\section{- Modern Dependency}

Today, poor countries are trapped by large debts which prevent them from developing. For example, between 1970 and 2002, the continent of Africa received $\$ 540$ billion in loans from wealthy nations through the World Bank and IMF. African countries have paid back $\$ 550$ billion of their debt but they still owe $\$ 295$ billion. The difference is the result of compound interest. Countries cannot focus on economic or human development when they are constantly paying off debt; these countries will continue to remain undeveloped. Dependency theorists believe large economic aid is not necessarily the key to reducing poverty and developing, but rather debt relief may be a more effective step (Hamza et al, 2005).

In addition, foreign trade and business often mitigate local governments' ability to improve the living conditions of their people. This trade often comes in the form of transnational corporations (TNCs). The governments of poor countries invite these TNCs to invest in their country with the hope of developing the country and bringing material benefit to the people. However, workers' time and energy are often poured into producing goods that they themselves will not consume.

\section{CONTEMPORARY THEORISTS OF THE DEPENDENCY SCHOOL}

Most of the dependency theorists use centre-periphery paradigm for analyzing the nature and scope of international relations as well as the nature of underdevelopment which characterizes the political systems of the underdeveloped societies like Africa.

The main advocates of Dependency Theory are Andre Gunder Frank, Wallerstein, Dos Santos, Osvaldo Sunkel, Celso Furtado, Rodolfo Stavenhagen, Euzo Falleto, Samir Amin, Walter Rodney, Claude Ake, Peter Eke, Frantz Fanon among others. The point of convergence for all of them is that fact that they agree that underdevelopment of the Third World countries is directly related to their neo-colonial existence, i.e., external dependence upon the developed countries.

According to Walter Rodney, in his work; "How Europe Underdeveloped Africa", he believed that Africa is a continent rich in natural resources. Copper, gold, diamonds, platinum, rubber, and aluminum are just some examples of what the land has to offer. In the nineteenth century, powerful and industrial Europe desired these raw materials in large quantities. The means of acquiring these resources inexpensively came through Europe's colonization and control of Africa, which also gave Europe access to cheap labor. Europe's economy flourished as Africa experienced a technical retrogression (Rodney, 1972)

Europe and other countries create allies with African nations in need of debt assistance or military protection, and dependence on Europe is sustained. Walter Rodney's belief is that the underdevelopment of Africa was caused by European colonialism and capitalism is supported by the dependency theory of global inequality. Colonists actively sought to stop any African industrialization by paying low prices and wages and corrupting the education system and government in many nations. Africa is still troubled by these structural problems and may never escape them until its dependency on Europe is significantly reduced.

For Andre Gunder Frank, the concepts of development and underdevelopment have meaning only when applied to nations within the capitalist world-economy. Frank envisions this world-economy as being divided into two major components, metropolis and satellite. These concepts are basically equivalent to Wallerstein's (1974) concepts of core and periphery. The flow of economic surplus in the world-economy is from the satellite 
(or periphery) to the metropolis (or core), and the world economy is organized to make this happen.

The underdeveloped nations therefore have become and remained underdeveloped because they are economically dominated by developed capitalist nations that have continually been extracting wealth from them. Frank (1966) has called this process the development of underdevelopment. In this view, the development of the rich nations and the underdevelopment of the poor ones are but two sides of the same coin as underdevelopment of some nations has made development for other nations possible and the development of other nations made the underdevelopment of other nations possible. The primary victims of this process are the vast majority of peasants and urban workers of the underdeveloped world itself. While the members of the developed nations do benefit from this, since, their standard of living is raised substantially, the greatest benefits go to capitalists in the metropolitan countries, as well as to the agricultural and industrial elites of the satellite countries, hence the latter have close economic and political ties to the metropolitan elite and play a crucial role in retaining, maintaining and sustaining the situation of economic dependency of their states.

For Frantz Fanon in his "The Wretched of the Earth" published in 1961, he provides a psychiatric and psychological analysis of the dehumanizing effects of colonization upon the individual, and the third world nations, and discusses the broader social, cultural, and political implications inherent to establishing a social movement for the decolonization of a person and of a people. Hence, he put forward the notion of psychological trappings; how developed world worked on our intelligence and mindset to colonize us, because the mind is a seat of decision making and once it is trapped, then the entire being or entity is trapped.

We should further note that through critiques of nationalism and of imperialism, Fanon presents a discussion of personal and societal mental health, a discussion of how the use of language (vocabulary) is applied to the establishment of imperialist identities, such as colonizer and colonized in order to teach and psychologically mold the native and the colonist into their respective roles as slave and master, and a discussion of the role of the intellectual in a revolution. Fanon proposes that revolutionaries should seek the help of the lumpen proletariat to provide the force required to effect the expulsion of the colonists.

Moreover, in traditional Marxist theory, the lumpen proletariat are considered the lowest, most degraded stratum of the proletariat social class especially criminals, vagrants, and the unemployed people who lacked the class consciousness to actively participate in the anti-colonial revolution.

In Peter Ekeh's “Colonialism and the Two Publics in Africa: A theoretical Statement”, published in 1975, he argued that colonialism in Africa created two publics mirroring the West. These two publics, private and public, are only similar with the West conceptually and theoretically. This is based on how they view politics. It is the view of what the public is that resulted to the problems of politics in Africa.

What are the two publics that Ekeh is referring to? He was referring to primordial and civic public. They have different standards of morality, yet linked to each other. Ekeh classified primordial as private and associated civic with colonial administration which is not private. Even though these two are different, politicians operate both in primordial and civic publics.

As Ekeh builds his argument, he took as back to how the war of independence in Africa has little to do with the needs and rights of the common people. It is a struggle for power between the African bourgeoisie and the European bourgeoisie. They used the fact that they acquired western education as a base for being the legitimate replacement of the colonizers. After independence Europe continued to remind Africans of their presence by making African leaders look like them.

The use of negative ideologies by colonial administrators against Africans later affected African politicians. They begin to believe that Africans did not contribute in the building of Africa. Ekeh further argued that the Western educated African 'now comes to look at Africans and African culture to some extent through the eyes of those European educators who determined the manner and content of the teaching he received to back up his claim. He further took an example of how historical facts are being taught in America compared to Africa.

The use of colonialism by Ekeh in shaping of African politicians led him to explain the two publics in terms of native sector and westernize sector. The native became a primordial. In this one morality is highly regarded. The westernized became the civic public were morality is not highly regarded. According to Ekeh, the primordial public has no economic reward. It is only used to gain respect and security while the civic public is for economic gain and one is not obligated to give back. As such morality is not highly regarded.

Furthermore, Claude Ake (1939-1996) was one of Africa's most distinguished political and social scientists and democrats of the twentieth century, writing widely and polemically on what were his life-long concerns of democracy and the future of the African continent. In his book; "Social Science as Imperialism: The Theory of Political Development" and published in 1979, he was primarily concerned with what he terms the most destructive form of imperialism namely scientific knowledge. Ake analyses how Western social sciences, whether consciously or unconsciously, imposed capitalist values and capitalist development on the Third World, and serve imperialist ends.

He unravels the theory of political development/westernization, exposing its ideological character and condemning 'Western development studies as worse than useless'. He then develops his analysis of the 
imperialist and ideological characteristics of Western social sciences to posit alternatives which may more successfully overcome permanent underdevelopment; and advocates a struggle for a new model of social sciences which is socialist-orientated, and that developing countries reject Western models.

\section{CRITICISMS OF THE DEPENDENCY THEORY}

In its emphasis on capitalist penetration of the periphery as the cause of all the evils of underdevelopment, the dependency school was accused of reductionism (Adegbagbo, Obinyan and Olurode, 1990). The obsession with the pernicious effects of capitalism prevented this approach from addressing itself to other areas of exploitation and domination in the Third World and it cannot be shown that there will not be exploitation once capitalism is eliminated. This approach turns out to be an extreme reaction to the modernization explanation that came before it. This argument was corroborated by Taylor (1979) as he provided one of the grounds for the inadequacies of the dependency submission when he explained that "In analyzing Third World societies, the sociology of underdevelopment uses a unilinear determinism, in which all non-economic elements are analyzed simply as effects of a capitalist penetration which universally blocks that development of the pre-existing society... Therefore, the conclusion that underdevelopment will simply be alleviated by the removal of capitalist penetration cannot be established..."

\section{DEPENDENCY THEORY AND NIGERIA'S UNDERDEVELOPMENT}

It should be pointed out here that the arrowhead factors nurturing underdevelopment in Nigeria is poor or bad governance and leadership inaction. In other words, it is on these two issues that other factors (both internal and external) are anchored. According to Nnadozie (2010), any attempt to address underdevelopment in Nigeria must be zeroed in on the problem of leadership inaction and bad governance. That Nigeria is overwhelmed by poverty and underdevelopment today can easily be attributed to poor, visionless, inept and selfish leadership (Achebe, 1998 and Nnadozie, 2006).

From the experiences of other continents, including America and Asia which passed through similar historical experiences as Africa such as colonialism and foreign domination, it is evident that their ability to jerk off the yoke of external domination and exploitation and leap into first and middle class industrialized societies never occurred until their leaders rejected foreign domination by taking concrete steps through their visionary, resilient, selfless and charismatic leadership.

Furthermore, the central factor sustaining underdevelopment in Nigeria is squarely a failure of leadership that is, the unwillingness or inability of its leaders to rise to the occasion in their responsibility and the challenge of personal example which are the hallmarks of the true leadership (Emeh, 2013). Nigeria has been less than fortunate in their leadership; and a fundamental element of this misfortune is the seminal as absence of intellectual rigour in the political thought of many of the founding fathers of the country; a penchant "to pious materialistic wooliness and self oriented pedestrianism" (Achebe, 1998). The ways by which the Nigerian leaders have sustained the underdevelopment of the country are as follows:

One is the manner Nigerian leaders have been mismanaging the enormous and God-given resources of the country. They waste the wealth of the nation by purchasing foreign and exotic goods and services for themselves, friends and cronies. Secondly, a large junk of that wealth was simply stolen through inflated contracts, frauds and other dubious methods. Apart from direct stealing of public fund, there is also the adoption of corrupted concept of development and development projects and programmes by governments in Nigeria, hence investments and public fund are for pecuniary reasons directed by our leaders at white elephant projects and programmes that do not yield dividends or create employment for the people as private interests override public interests. A colossal sum of public money has been lost in this manner.

Nigerian leaders who loot their state treasuries often take the monies to foreign banks mostly in Europe and America, thereby depriving the country even the benefits of reaping from investing the stolen money in the country; as a large chunk of state resources should have been channeled into productive sectors of the economy to strengthen social services, especially in the areas of health, education, infrastructural facilities and energy is lost through various forms of corrupt practices. The money all end up in the pockets of few privileged state/government officials and the people are worst off for it (Nnadozie, 2010).

Eranga (2009) wrote that Nigeria is besieged with huge debt burden and unequal foreign exchanged and that her economy is in a state of near-collapse. Despite the debt cancellation by the Paris Club, Nigeria still owes huge debts, as the nation's total debt stock as at end of 2010 stood at $\$ 4.7$ billion for external debt and \#4.5 trillion for domestic debt (Babajide, 2011). Inflation is on the increase day in and day out, reaching to its peak when it was rated at 10.5 percent in October 2011.

These factors are clear indicators of severe underdevelopment in Nigeria when compared to most developing countries of Africa and when consideration is paid to the amount of loot that goes in the higher and highest echelon of our public and political realms. Such categorization has led to the assertion that Nigerian economy presently is characterized by galloping inflation, unequal foreign exchange rate exasperated by 
devalued currency and persistent dependence on importation, widespread unemployment, dilapidated infrastructures exemplified in the nature of the Nigeria roads and death conservative nature of Nigerian hospitals, epileptic power supply that has helped crippled all aspect of the societal survival possibility, near death state of the educational sector leading to a unavoidable brain drain. Entrepreneurship has died as corruption in the system has left nothing to desire in hard work and labour as youths are now concerned with money-making irrespective of how it comes and who gets hurt in the process. This is why diligence and honesty has been dethroned while dishonesty and greed has been enthroned. This also explains why merit has died in Nigeria making way for mediocrity (Eme and Emeh, 2012).

\section{MY POSITION}

As cursory look at the work of Huntington (1993) in his "The Clash of Civilizations"; that following the fall of the Berlin Wall in 1989, the identity of a nation is less defined by belonging to a single nation. With this, he showed that we have moved from a bipolar world to a multi polar world which is divided into three parts: the democratic and rich Western world, the poorer Communist world, and the Third World. The Third World countries were the place of clashes between the West and the Communist Bloc during the Cold War. In a multipolar world, oppositions are not so much ideological, political or economic, than cultural. To define the nature of their identities, civilizations define themselves in terms of religion, language, history, values, customs and institutions. In other words, we need the Nigerian identity and jettison the fact that we are suffering from our contacts with the Europeans. China, Malaysia, India and some other countries were colonised but they identified their culture and values which was built on to position them as growing economies today.

Drawing from Paul Arkwright (2017), the British High Commissioner to Nigeria in an interview with the Vanguard Newspaper; key stakeholders including the government, policy makers and its citizens, the following should be put to consideration. They are instructive for our development and should serve as our food for thought.

1. Nigeria should look inwards and stop blaming its colonial masters for the absence of industrial development.

2. Nigeria has the Federal, State and Local Government, as well as the human resources and the money. It is not the British that determine how we appropriate and spend these resources, but our leaders, hence, the poor administrative structure and the ineffective utilisation of our resources has bred underdevelopment for Nigeria.

3. In Nigeria, for every situation, the country will come up with two committees, different commissions and commence many legs of addressing the situation; but nothing practical will be taken to address such situation.

4. That one big challenge for the country is corruption, and it is not only by arresting big names and sending them to jail. It is about dealing with the corrosive nature of corruption that occurs in everyday Nigeria. This must be done through the building of institutions that will outlive even the President and become a yardstick in measuring transparency and accountability future dealings.

I will like to conclude this paper with a quotation by Karl Marx where he said:

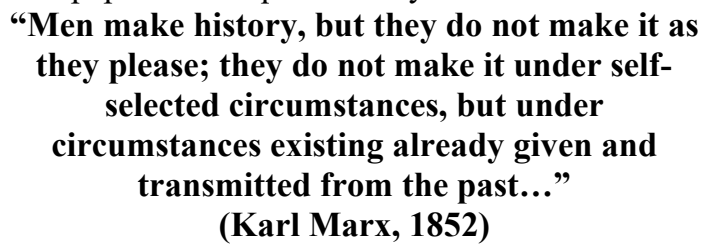

The above tells us that we are creator of our own lives, though it is not our choice to make it how we want but the story can be retold and corrected ourselves if not pleased. We are special creatures who acquire our own language, customs, beliefs, norms as passed on from one generation to another, and whatever it is we might choose to create or become, the ball is in our court, and our resources can be better harnessed to achieve that desired developmental state like China and India.

\section{REFERENCES}

Achebe, C (1983) The trouble with Nigeria. Enugu; Forth dimension Publishers

Adegbagbo S.A, Obiyan T.U. and Olurode L (1990). Family and Social Change. Essays in Sociological and Social Welfare Administration. Lagos, Rebonik Publications Limited.

Amin S. (1976), 'Unequal Development: An Essay on the Social Formations of Peripheral Capitalism' New York: Monthly Review Press.

Amin S. (1976), 'Unequal Development: An Essay on the Social Formations of Peripheral Capitalism' New York: Monthly Review Press.

Andre Gunder Frank, (1972), "The Development of Underdevelopment," in James D. Cockcroft, Andre Gunder 
Frank, and Dale Johnson, eds., Dependence and Underdevelopment. Garden City, New York: Anchor Books.

Cardoso, F. H. and Faletto, E. (1979), 'Dependency and development in Latin América'. University of California Press.

Claude Ake (1979). Social Science as Imperialism: The Theory of Political Development. 2nd Edition, Ibadan University Press.

Eme, O. I \& Emeh, I.E.J (2012) "Bureaucracy and Rural Development; the Role of Public Administration in National Development: The Nigerian Perspective". Global Journal of Management and Business Research. Volume 12 Issue 4. Pp.19-40.

Emeh, Ikechukwu E. (2013). Dependency Theory and Africa's Underdevelopment: a Paradigm Shift from Pseudo-Intellectualism: the Nigerian Perspective. International Journal of African and Asian Studies - An Open Access International Journal Vol.1.

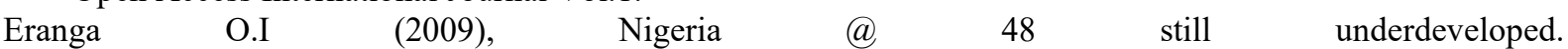
"http://www.nigerianobservernews.com"_www.nigerianobservernews.com_

Ferraro, Vincent (1996), - "Dependency Theory: _ An Introduction", http://marriottschool.byu.edu/emp/WPW/pdf/class/Class_6 The_Dependency_Perspective.pdf

Huntington S. (1993) The Clash of Civilizations. Foreign Affairs, Vol. 72, No. 3, pp. 22-49.

James, Paul (1997). Post-Dependency: The Third World in an Era of Globalism and Late Capitalism. Alternatives: Social Transformation and Human Governance. 22 (2): 205-26.

Köhler G. and Tausch A. (2002) Global Keynesianism: Unequal exchange and global exploitation. Huntington NY, Nova Science.

Laclau E. (1971). Feudalism and Capitalism in Latin America. New Left Review. No 67.

Nnadozie, O.U (2006) External forces, Democracy and underdevelopment in Nigeria; a prognosis. A paper presented at Two-Day International Workshop on global and Regional Hegemonic dilemmas in the South held in Bangkok Thailand between 29th and 30th.

Nnadozie, O.U (2010) Why poverty in Africa. Nsukka; Bel's Book.

Peter P. Ekeh (1975). Colonialism and the Two Publics In Africa: A Theoretical Statement. Comparative Studies in Society and History. Vol 17, No 1. Pp. 91-112

Rapley, J. (1996), Understanding Development: Theory and Practice in the Thirld World, Boulder: Lynne Riener. Reyes, Giovanni E. (2002), "The Argentinean Crisis and the Theory of Economic and Social Development", The New Paradigms of International Cooperation, No 64, January - April.

Richards,A and J. Waterbury (1996) (Second Ed.) A Political Economy of the Middle East: State, Class and Economic Development, Boulder: Westview Press.

Rodney, W. (1972). How Europe underdeveloped Africa. Beyond borders: Thinking critically about global issues, 107-125.

Taylor J.G (1979). From Modernisation to Modes of Production. Critique of the Sociologies of Development and Underdevelopment. Lodon. Macmillian Press Ltd.

Vanguard Newspaper- 8th April, 2017. "Nigeria must stop blaming colonialism for its woes- British High Commissioner".

Vincent Ferraro (1996). Dependency Theory: An Introduction Mount Holyoke College South Hadley, MA

Wallerstein, I. (1974), the Modern World-System. New York, NY: Academic Press. 